\title{
The damaging effects of short chain fatty acids on Escherichia coli membranes
}

\author{
Liam A. Royce • Ping Liu • Matthew J. Stebbins • \\ Benjamin C. Hanson • Laura R. Jarboe
}

Received: 15 April 2013 /Revised: 8 July 2013 / Accepted: 9 July 2013 /Published online: 3 August 2013

(C) The Author(s) 2013. This article is published with open access at Springerlink.com

\begin{abstract}
Carboxylic acids are an attractive biorenewable chemical. However, like many other fermentatively produced compounds, they are inhibitory to the biocatalyst. An understanding of the mechanism of toxicity can aid in mitigating this problem. Here, we show that hexanoic and octanoic acids are completely inhibitory to Escherichia coli MG1655 in minimal medium at a concentration of $40 \mathrm{mM}$, while decanoic acid was inhibitory at $20 \mathrm{mM}$. This growth inhibition is $\mathrm{pH}$ dependent and is accompanied by a significant change in the fluorescence polarization (fluidity) and integrity. This inhibition and sensitivity to membrane fluidization, but not to damage of membrane integrity, can be at least partially mitigated during short-term adaptation to octanoic acid. This short-term adaptation was accompanied by a change in membrane lipid composition and a decrease in cell surface hydrophobicity. Specifically, the saturated/unsaturated lipid ratio decreased and the average lipid length increased. A fatty acid-producing strain exhibited an increase in membrane leakage as the product titer increased, but no change in membrane fluidity. These results highlight the importance of the cell membrane as a target for future metabolic engineering efforts for enabling resistance and tolerance of desirable biorenewable compounds, such as carboxylic acids. Knowledge of these effects can help in the engineering of robust biocatalysts for biorenewable chemicals production.
\end{abstract}

Electronic supplementary material The online version of this article (doi:10.1007/s00253-013-5113-5) contains supplementary material, which is available to authorized users.

L. A. Royce · M. J. Stebbins • B. C. Hanson · L. R. Jarboe $(\bowtie)$ Department of Chemical and Biological Engineering, Iowa State University, 3051 Sweeney Hall, Ames, IA 50011, USA

e-mail: ljarboe@iastate.edu

P. Liu $\cdot$ L. R. Jarboe

Interdepartmental Microbiology Program, Iowa State University,

Ames, IA 50011, USA
Keywords Membrane lipids · Escherichia coli $\cdot$ Bacterial inhibition · Short chain fatty acids · Membrane fluidity · Tolerance

\section{Introduction}

Biofuels and biorenewable chemicals are an increasingly important area of research. Government policies are demanding cleaner, safer, and more sustainable processes for production of energy and chemicals (Chambers and Muecke 2010; DOE 2012). Development of drop-in replacements of petroleumderived compounds is key to a sustainable carbon-based chemicals industry (Bozell and Petersen 2010; Nikolau et al. 2008). To this end, there is substantial interest in producing biorenewable fuels and chemicals from biomass (Centi and van Santen 2007; Erickson et al. 2012; Wackett 2008). Carboxylic acids can serve as precursors to many molecules in industrial applications. For example, carboxylic acids can be converted into alkanes for diesel fuel applications (Mäki-Arvela et al. 2007) or into $\alpha$-olefins for polymer synthesis applications (Alonso et al. 2010; Shanks 2010). $\beta$-Hydroxyalkanoates, another molecule of interest in biorenewables research, can be made into a polymer from carboxylic acids as a monomer (Chen et al. 2001). Short chain fatty acids (SCFAs) may be more desirable for polymer synthesis in order to control the number of carbons in the polymer backbone, whereas the larger molecules are applicable for biodiesel.

Fatty acids or carboxylic acids with 12-18 carbons are common in biology as the main components of bacterial cell membranes. The fatty acid biosynthesis pathway is an iterative way to modulate the carbon chain length of molecules as desired (Nikolau et al. 2008; Zhang et al. 2011), and thus there is extensive interest in exploiting this system to make a broad range of biorenewable chemicals. 
In addition to their potential as biorenewable chemicals, fatty acids are used in a number of industries ranging from soap to preservatives. For example, the food industry uses free fatty acids as a preservative to increase shelf life (Kabara 1984; Kabara and Marshall 2005; Makkar and Cameotra 2002). Therefore, it is known that SCFAs are inhibitory to microbial growth, as reported by a number of sources (Desbois and Smith 2010; Kabara and Marshall 2005; Liu et al. 2013; Yang et al. 2010). This usefulness as a preservative could in turn be a problem in the fermentative production of SCFAs as biorenewable chemicals. Small organic acids (i.e., formic, acetic, propanoic, and butyric acids) are a natural byproduct of fermentation, especially in the human intestine, where concentrations can range from 20 to $120 \mathrm{mM}$ (Cummings and Macfarlane 1991). Therefore, many enteric bacteria have natural pathways and mechanisms for mitigating toxicity of small organic acids, including transport, altered metabolism, acid resistance, and stress proteins (Diez-Gonzalez and Russell 1999; Polen et al. 2003). Individual response mechanisms are reported in literature, but as a whole, the entire response network is not clear. Moreover, the mechanisms can be molecule-dependent and even have opposing effects in some cases, thereby confounding analysis (Kirkpatrick et al. 2001; Russell 1991).

Inhibition of the biocatalyst by the desired product is a common problem in the fermentative production of biorenewable fuels and chemicals, but knowledge of the mechanism of inhibition can aid in the design of strategies for engineering tolerance (Jarboe et al. 2011). Much work has been done to address microbial inhibition by biofuels such as ethanol and butanol (Huffer et al. 2011; Jarboe et al. 2007; Minty et al. 2011; Reyes et al. 2011); however, the mechanisms of SCFA toxicity in Escherichia coli are not well understood. Specifically, our knowledge of the mechanism of inhibition by hexanoic (C6), octanoic (C8), and decanoic acids $(\mathrm{C} 10)$ remains incomplete (Carpenter and Broadbent 2009; Ricke 2003). Recently, Hyldgaard and coworkers (2012) showed the mechanisms of inhibition of monocaprylate, a monoester containing octanoate. Their work addressed the cellular physiology as described by atomic force microscopy, dye leakage, and the lamellar phase of model membranes. While their study is an excellent qualitative analysis, more work is needed for a quantitative assessment of the mechanisms of inhibition.

Lennen et al. (2011) and Lennen and Pfleger (2013) indicated that toxicity may adversely affect yields of free fatty acid production. Their transcriptome analysis led to the proposition that the SCFAs damage the cell membrane; similar effects were proposed in Brynildsen and Liao's (2009) transcriptome analysis of butanol challenge. Here, we confirm and quantify the potentially damaging effects of SCFAs on the $E$. coli cell membrane and the possible mechanism the $E$. coli uses to increase tolerance to SCFAs. In addition to observing this damage to the membrane during exogenous challenge with SCFAs, we also observe similar damage during carboxylic acid production.

\section{Materials and methods}

Strains and growth conditions

E. coli strains were obtained from ATCC (Manassas, VA, USA) (Table 1) and were grown with $1 \mathrm{ml}$ MOPS minimal medium (Wanner 1994) with $2 \%$ dextrose in a 5 -ml sterile culture tube shaking horizontally at $100 \mathrm{rpm}$ at $37^{\circ} \mathrm{C}$ for $24 \mathrm{~h}$. Overnight cultures were diluted to an optical density of 0.05 at $550 \mathrm{~nm}\left(\mathrm{OD}_{550}\right)$ for specific growth measurements and diluted to 0.1 for cell viability, fluidity, leakage, lipid composition, and hydrophobicity measurements. Adapted E. coli were grown to midlog $\left(\mathrm{OD}_{550} \sim 0.8\right)$, centrifuged (Fisher Scientific Marathon 21000R, Thermo IEC 6555C rotor; Fisher Scientific, Hampton, $\mathrm{NH}$, USA) at $5,000 \times \mathrm{g}$ for $15 \mathrm{~min}$, resuspended in MOPS medium with $2 \%$ dextrose containing $\mathrm{C} 8$ and incubated for $3 \mathrm{~h}$ at $37{ }^{\circ} \mathrm{C}$ without shaking. Strain ML103 + pXZ18Z (Ranganathan et al. 2012) (obtained from Dr. Ka-Yiu San, Rice University, Houston, TX, USA) was grown in a 500$\mathrm{ml}$ bioreactor in MOPS $+2 \%$ dextrose $+100 \mu \mathrm{M}$ IPTG at $30{ }^{\circ} \mathrm{C}, 300 \mathrm{rpm}$. The bioreactor was $\mathrm{pH}$ and temperature controlled. Foam was controlled with automated addition of $50 \%$ solution of antifoam B silicone emulsion (J.T. Baker, Phillipsburg, NJ, USA).

Determination of the specific growth rate

The specific growth rate was determined by the $\mathrm{OD}_{550}$ measurements in the exponential phase of cultures in $25 \mathrm{ml}$ MOPS medium with $2 \%$ dextrose with various concentrations of fatty acid solutions (4 M stock in $100 \%$ ethanol) in 250-ml baffled shake flasks shaking at $150 \mathrm{rpm}$ in a rotary shaker. Adding the same volume amount of $100 \%$ ethanol as a control did not affect the growth rate. The initial medium $\mathrm{pH}$

Table 1 Strains and plasmids used in this study

\begin{tabular}{|c|c|c|}
\hline Strain and plasmid & Genotype & Reference \\
\hline $\begin{array}{l}\text { MG1655 } \\
\text { ATCC\#700926 }\end{array}$ & F- lambda- ilvG-rfb-50 rph-1 & Wildtype \\
\hline $\begin{array}{l}\text { E. coli } \mathrm{W} \\
\text { ATCC\#9637 }\end{array}$ & - & Wildtype \\
\hline $\begin{array}{l}\text { E. coli Crooks } \\
\text { ATCC } \# 8739\end{array}$ & - & Wildtype \\
\hline ML103 & $\mathrm{MG} 1655 \Delta f a d D$ & $\begin{array}{l}\text { Li et al. } \\
\quad(2012 a)\end{array}$ \\
\hline pXZ18Z & $\begin{array}{l}\text { pTrc99a-acyl Thioesterase } R \text {. } \\
\text { communis-fabZ }\end{array}$ & $\begin{array}{r}\text { San et al. } \\
\text { (2011) }\end{array}$ \\
\hline
\end{tabular}


was adjusted to 7.0 in all cases except when modulating the $\mathrm{pH}$ from 5 to 7 . The medium $\mathrm{pH}$ during fermentation maintained a $\mathrm{pH}$ between 6.5 and 7.0 when estimating the specific growth rate. The line of fit when estimating the specific growth rate had an $R^{2}$ value $\geq 0.9$.

\section{Viability assays}

E. coli cell viability was assessed by colony counting and propidium iodide (PI) using flow cytometry assays. The samples were prepared as follows: cells were centrifuged at $5,000 \times g, 4{ }^{\circ} \mathrm{C}$ for $15 \mathrm{~min}$, washed twice with phosphate buffer saline diluted to the working concentration (PBS, 10× powder concentrate; Thermo Fisher Scientific, Vista, CA, USA) $\mathrm{pH}=7.0$, and resuspended in PBS. The cells were treated with $30 \mathrm{mM} \mathrm{C} 8$ and incubated at $37^{\circ} \mathrm{C}$ for $30 \mathrm{~min}$. The colony counting assay was performed as follows: the samples were diluted serially using sterile water and plated out on MOPS + $2 \%$ glucose plates. Two replicates were conducted. The PI assay was performed as follows: the $\mathrm{OD}_{550}$ of each sample was diluted to $1 \times 10^{6}$ cells $/ \mathrm{ml}\left(\mathrm{OD}_{550}=0.005\right)$. Then, $200 \mu \mathrm{l}$ diluted cell culture with $100 \mu \mathrm{g} / \mathrm{ml}$ PI was used for flow cytometry. Cells without PI were also included.

Fitting specific growth rate data as a function of $\mathrm{pH}$ and protonated octanoic acid

After determination of the specific growth rate by $\mathrm{OD}_{550}$ measurements, the specific growth rate data was fitted using the following equations derived from the HendersonHasselbach equation:

$\mathrm{C} 8_{\mathrm{t}}=\mathrm{C} 8 \mathrm{O}^{-}+\mathrm{C} 8 \mathrm{OH}$

$\mathrm{C} 8 \mathrm{OH}=\frac{C 8_{\mathrm{t}}}{1+10^{\left(\mathrm{pH}-\mathrm{p} K_{\mathrm{a}}\right)}}, \mathrm{p} K_{\mathrm{a}}=4.89$,

where $\mathrm{C} 8_{\mathrm{t}}$ is the total concentration of $\mathrm{C} 8, \mathrm{C}^{-} \mathrm{O}^{-}$is the undissociated form, and $\mathrm{C} 8 \mathrm{OH}$ is the protonated form.

\section{Determination of membrane fluidity}

Membrane fluidity can be measured as a fluorescence polarization or anisotropy value, which corresponds to how a fluorescent probe inside the membrane reacts to polarized light (Mykytczuk et al. 2007). Harvested cells were treated according to the protocol described by Beney et al. (2004). Briefly, the samples were washed twice in PBS, $\mathrm{pH}=7.0$, resuspended $\left(1 \times 10^{8}\right.$ cells $\left./ \mathrm{ml}\right)$, and incubated at $37{ }^{\circ} \mathrm{C}$ for 30 min with 1,6-diphenyl-1,3,5-hexatriene (DPH; supplied by Life Technologies, Carlsbad, CA, USA) at a concentration of $0.2 \mu \mathrm{M}(0.2 \mathrm{mM}$ stock solution in tetrahydrofuran). Fluorescence polarization values were determined by using a
Synergy 2 Multi-Mode microplate reader from BioTek using sterile black-bottom Nunclon delta surface 96 -well plates. The filters were $360 / 40 \mathrm{~nm}$ fluorescence excitation and 460/40 nm fluorescence emission filters from BioTek. The excitation polarized filter was set in the vertical position. The emission polarized filter was set either in the vertical $\left(I_{\mathrm{VV}}\right)$ or horizontal $\left(I_{\mathrm{VH}}\right)$ position. The polarization value is calculated by the following formula:

$P=\frac{I_{\mathrm{VV}}-I_{\mathrm{VH}} G}{I_{\mathrm{VV}}+I_{\mathrm{VH}} G}$

where $G$ is the grating factor, assumed to be 1 . The cells were treated with octanoic acid at $\mathrm{pH} 7.0$ just before measurements.

\section{Membrane leakage}

E. coli cells were grown in the same condition as the fluidity measurements and processed at the same time. The leakage test was performed according to Osman and Ingram (1985). Cells were centrifuged at $5,000 \times \mathrm{g}, 4{ }^{\circ} \mathrm{C}$ for $15 \mathrm{~min}$, washed twice with $\mathrm{PBS} \mathrm{pH}=7.0$ and resuspended in PBS at a final $\mathrm{OD}_{550}=10\left(1.69 \times 10^{9}\right.$ cells $\left./ \mathrm{ml}\right)$. The cells were then treated with octanoic acid at $\mathrm{pH} 7.0$, mixed well by pipetting and incubated at $37^{\circ} \mathrm{C}$ for $30 \mathrm{~min}$. The cells were then centrifuged at $16,873 \times g(14,000 \mathrm{rpm}) 4{ }^{\circ} \mathrm{C}$ for $5 \mathrm{~min}$ and magnesium in the supernatant was measured by infinity magnesium reagent (Thermo Fisher Scientific, Vista, CA, USA) and spectrophotometer with temperature control at $30^{\circ} \mathrm{C}$ (Varian Cary 50 Series; Agilent Technologies, Santa Clara, CA, USA). The leakage values of magnesium were expressed as a percentage of magnesium released by chloroform with vortexing for $30 \mathrm{~s}$. ( $0.2 \mathrm{ml}$ chloroform per $2 \mathrm{ml}$ of suspension).

Membrane lipid composition

MG1655 cells were harvested at midlog, resuspended in $25 \mathrm{ml}$ medium with 0-30 mM C8 $\mathrm{pH} 7.0$, and incubated for $3 \mathrm{~h}$. The cells were washed twice in cold sterile water and split into four tubes. Then, $50 \mu \mathrm{l}$ of $0.4 \mathrm{mg} / \mathrm{ml} \mathrm{C13/C19}$ (tridecanoic acid/ nonadecanoic acid) in chloroform was added as internal standards. The Bligh and Dyer method was adapted for membrane lipid extraction (Bligh and Dyer 1959). Briefly, the cells were resuspended in $1.4 \mathrm{ml}$ methanol, sonicated for three 20 -s bursts, and incubated at $70{ }^{\circ} \mathrm{C}$ for $15 \mathrm{~min}$. The cells were then centrifuged at $5,000 \times \mathrm{g}$ for $10 \mathrm{~min}$ and the supernatant was collected. The cell pellet was further treated with $750 \mu \mathrm{l}$ chloroform and incubated at $37{ }^{\circ} \mathrm{C}$ for 5 min shaking in a horizontal shaker at $150 \mathrm{rpm}$. A methanol/water/chloroform (1.9:1.9:1) ternary mixture was used to phase-separate the extracted lipids in the chloroform layer. The free fatty acids were concentrated with a N-Evap nitrogen tree evaporator 
(Organomation Associates). The lipids were methylated into fatty acid methyl esters (FAMEs) at $80^{\circ} \mathrm{C}$ for 30 min by adding $2 \mathrm{ml} 1 \mathrm{~N}$ hydrochloric acid in methanol to samples concentrated under nitrogen, then $1 \mathrm{ml} 0.9 \%$ sodium chloride solution was added. The FAMEs were extracted with hexane, filtered with a $0.2 \mu \mathrm{m}$ polytetrafluoroethylene (PTFE) filter, and analyzed by gas chromatograph-flame ionization detector/mass spectrometer (GC-FID/MS) using the following instruments: an Agilent 7890 gas chromatography, an Agilent 5975 mass spectroscopy, and a Agilent $190915-43330 \mathrm{~m} \times 0.25 \mathrm{~mm} \times 0.25 \mathrm{~mm}$ column (Agilent Technologies). The initial temperature was set at
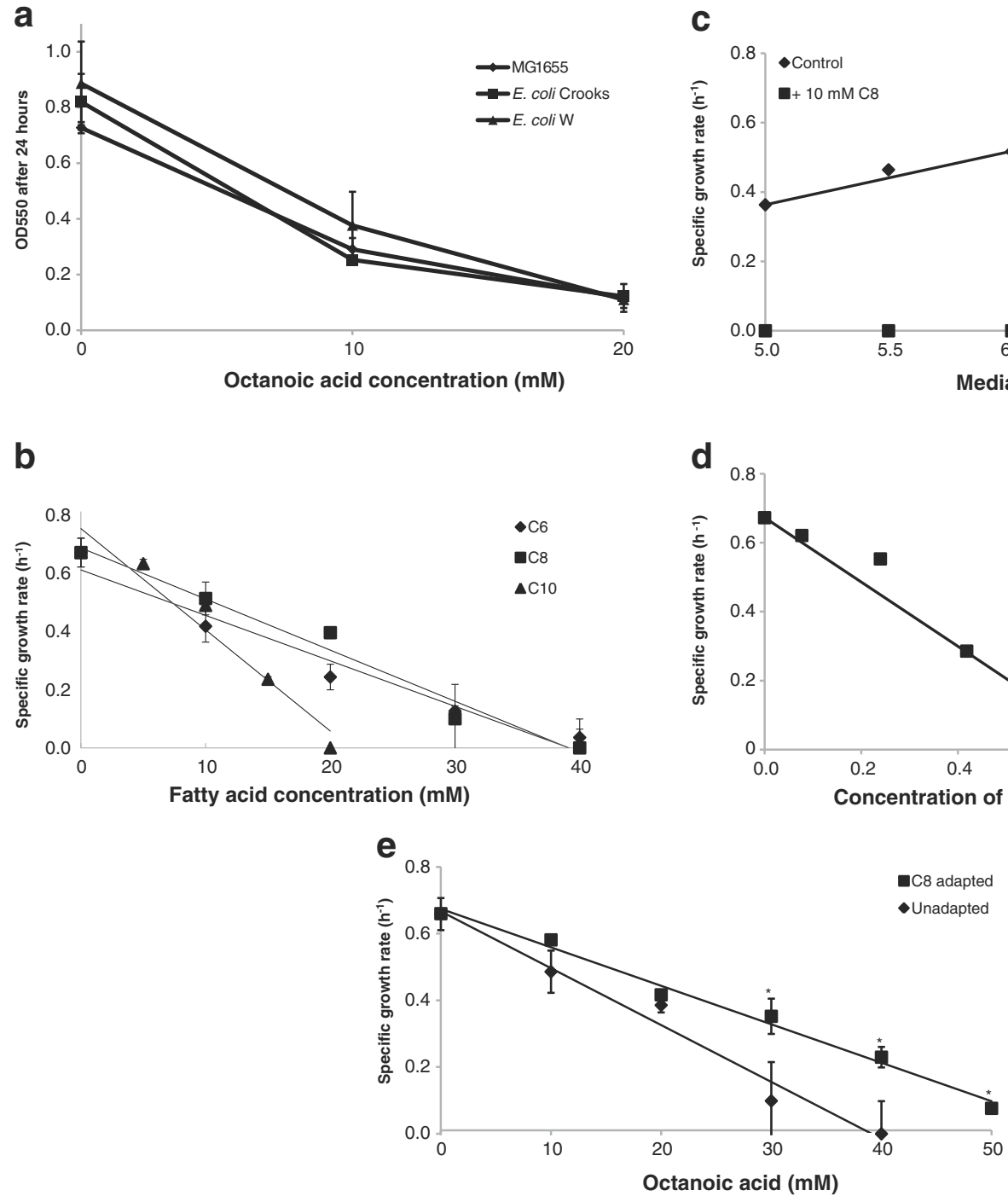

Fig. 1 SCFAs inhibit the growth of $E$. coli, though adaptation can increase tolerance. a Optical density at $24 \mathrm{~h}$ of three $E$. coli laboratory strains in the presence of octanoic acid. b Specific growth rate of MG1655 as a function of SCFA concentration and chain length. c Specific growth rate of MG1655 upon addition of $10 \mathrm{mM} \mathrm{C8}$ as a function of medium $\mathrm{pH}$. $\mathbf{d}$ The specific growth rate modeled as a function of the concentration of protonated C8. e Specific growth rate of MG1655
$50{ }^{\circ} \mathrm{C}$, holding for $1 \mathrm{~min}$, with the following temperature ramp: $20{ }^{\circ} \mathrm{C} / \min$ to $140{ }^{\circ} \mathrm{C}, 4{ }^{\circ} \mathrm{C} / \min$ to $220{ }^{\circ} \mathrm{C}$, and $5{ }^{\circ} \mathrm{C} / \mathrm{min}$ to $280^{\circ} \mathrm{C}$ with $1 \mathrm{ml} / \mathrm{min}$ helium carrier gas. The relative retention factor of $\mathrm{C} 19$ was used to adjust the relative amounts of the individual fatty acids analyzed (Tvrzická et al. 2002).

The saturated/unsaturated ratio $(\mathrm{S} / \mathrm{U})$ and weightedaverage lipid length were calculated as follows:

$S / U=\frac{\mathrm{C} 12: 0+\mathrm{C} 14: 0+\mathrm{C} 16: 0+\mathrm{C} 18: 0}{\mathrm{C} 16: 1+\mathrm{C} 17 \mathrm{cyc}+\mathrm{C} 18: 1+\mathrm{C} 19 \mathrm{cyc}}$
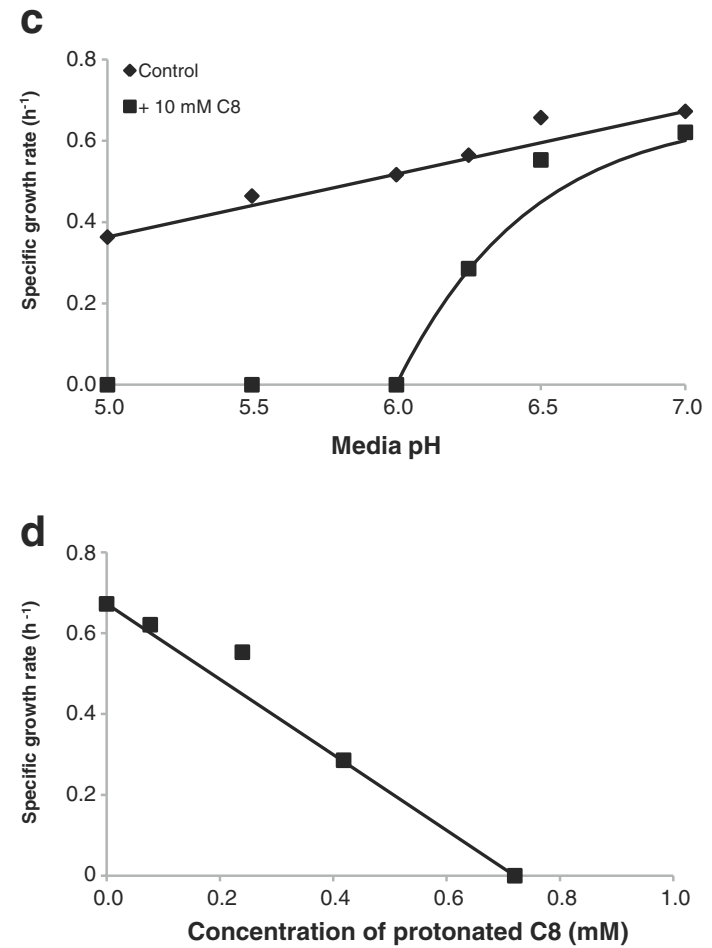

in media of increasing $\mathrm{C} 8$ concentrations of MG1655 after short-term ( $3 \mathrm{~h})$ adaptation to $30 \mathrm{mM} \mathrm{C} 8$. An asterisk indicates a significant difference $(p<0.05)$ in the growth rate of adapted $E$. coli from its corresponding unadapted $E$. coli growth rate value at that concentration. All data represents the average of at least three biological replicates, with error bars indicating standard deviation values 
$L=\frac{12 * C 12: 0+14 * C 14: 0+16 *(C 16: 0+C 16: 1+C 17 c y c)+18^{*}(C 18: 0+C 18: 1+C 19 c y c)}{\mathrm{C} 12: 0+\mathrm{C} 14: 0+\mathrm{C} 16: 0+\mathrm{C} 16: 1+\mathrm{C} 17 \mathrm{cyc}+\mathrm{C} 18: 0+\mathrm{C} 18: 1+\mathrm{C} 19 \mathrm{cyc}}$

Hydrophobicity test

Unadapted and $30 \mathrm{mM} \mathrm{C8}$ adapted cells were harvested at midlog, centrifuged at 5,000 $\times \mathrm{g}$ for $20 \mathrm{~min}$ and resuspended in PBS buffer to $\mathrm{OD}_{550}=0.591\left(1 \times 10^{8}\right.$ cells $\left./ \mathrm{ml}\right)$. Then, $1.2 \mathrm{ml}$ cells were added to $2.4 \mathrm{ml}$ hexane as previously described (Zhang et al. 2007). The microbial adhesion to hydrocarbons (MATH) value was calculated as previously described (Aono and Kobayashi 1997).

\section{Statistical analysis}

The $p$ values were obtained using one-way ANOVA and Tukey-Kramer pairs analysis with the JMP v/8.02 statistical program (SAS Institute, Cary, NC, USA). The statistical significance of the linear regression estimates of the weight-average lipid length was performed in JMP using the $t$-test on the intercept and the slope (concentration).

\section{Results}

Strain comparison

It is known that SCFAs are toxic to E. coli (Desbois and Smith 2010; Kabara and Marshall 2005; Yang et al. 2010). In this study, we performed a side-by-side comparison of three $E$. coli strains frequently used for metabolic engineering projects. Specifically, we tested and compared for their octanoic acid tolerance (Fig. 1a). The C8 sensitivity was similar for all strains and substrain MG1655 was selected for subsequent experiments, given that it is the most well characterized substrain.

\section{Specific growth rate of MG1655}

The specific growth rate of MG1655 under SCFA stress was determined at a variety of concentrations and three chain lengths (Fig. 1b). All carbon chain lengths (C6, C8, C10) were completely inhibitory by $40 \mathrm{mM}$, with $\mathrm{C} 10$ being completely inhibitory at $20 \mathrm{mM}$. While C6 and C8 imposed roughly the same degree of inhibition, $\mathrm{C} 10$ was more inhibitory than $\mathrm{C} 6$ or $\mathrm{C} 8$. Thus, there is a slight association between SCFA toxicity and SCFA chain length, although not to the degree observed with yeast (Liu et al. 2013).
It is known that the inhibitory action of free fatty acids on microorganisms is $\mathrm{pH}$-dependent (Yang et al. 2010). Therefore, the medium $\mathrm{pH}$ was modulated to quantitatively describe the inhibitory behavior on the specific growth rate. In the absence of octanoic acid, medium $\mathrm{pH}$ has a roughly linear impact on the $E$. coli specific growth rate (Fig. 1c). However, in the presence of $10 \mathrm{mM} \mathrm{C} 8$, the relationship between medium $\mathrm{pH}$ and $E$. coli growth changed to a logarithmic decay. Comparing the growth rate to the concentration of protonated $\mathrm{C} 8$ instead of bulk medium $\mathrm{pH}$ restores the linear relationship with specific growth rate (Fig. 1d). This result is consistent with previous reports that the protonated form has a greater permeability of the membrane and is therefore more toxic to microorganisms. SCFAs are known to cause cell death (Desbois and Smith 2010). Therefore, we assessed the cell viability using colony counting and PI (flow cytometry) assays. With the addition of $30 \mathrm{mM} \mathrm{C} 8,54 \pm 26 \%$ of cells remained viable based on colony counting assays and $49 \pm 12 \%$ remained viable based on PI assays.

\section{Short-term adaptation}

The results described above provide insight into the sensitivity of $E$. coli to SCFA. In order to gain insight into the $E$. coli response to this inhibition, short-term adaptation was performed. MG1655 cells were adapted to octanoic acid during $3 \mathrm{~h}$ of growth in the presence of $30 \mathrm{mM} \mathrm{C} 8$ at $\mathrm{pH} 7.0$ before inoculation into fresh medium and re-assessing the specific growth rate. The adapted cells had significantly increased $\mathrm{C} 8$ tolerance, as evidenced by their ability to grow faster than the unadapted cells in the presence of 30 and $40 \mathrm{mM} \mathrm{C} 8$ and demonstration of slight growth in the presence of $50 \mathrm{mM} \mathrm{C} 8$ (Fig. 1e).

These results demonstrate that changes that occur during SCFA adaptation increase the tolerance of $E$. coli to the stresses imposed by SCFAs. Identification of these changes can provide insight into the mechanism of SCFA toxicity.

\section{Membrane fluidity and leakage}

Previous studies have concluded that SCFA toxicity is imposed by membrane damage (Desbois and Smith 2010; Lennen et al. 2011). We quantified this damage in terms of the impact on both membrane fluidity and membrane integrity. Measurements of the membrane fluidity and membrane leakage confirm that SCFAs damage the cell membrane 

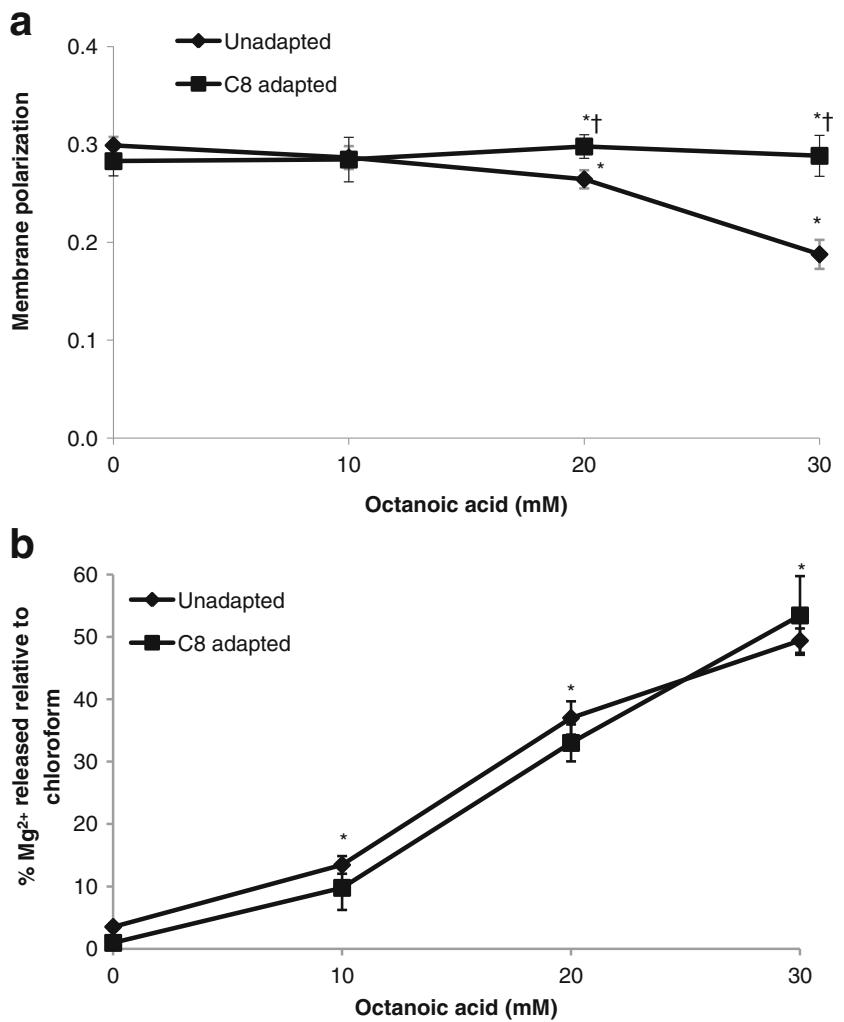

Fig. 2 Increasing the concentration of octanoic acid increases the membrane fluidity and membrane leakage; adapted cells can resist the fluidizing effect, but not leakage. a Fluorescence polarization of unadapted MG1655 and $30 \mathrm{mM} \mathrm{C8}$ adapted MG1655 during log phase with C8 challenge. The polarization values are unitless. Eight technical replicates were averaged. An asterisk indicates significantly different values from the $0 \mathrm{mM}$ control and a dagger symbol indicates significantly different values between adapted cells and unadapted cells $(p<0.05)$. b Membrane leakage of $E$. coli in log phase with $\mathrm{C} 8$ challenge. The membrane leakage is reported as percent relative to the magnesium released during chloroform treatment. Three technical replicates were averaged for each treatment for the leakage test. All data represents the average of at least three biological replicates, with error bars indicating standard deviation values

(Fig. 2). As the concentration of octanoic acid increased, the fluorescence polarization significantly decreased in unadapted E. coli, corresponding to increased fluidity (Fig. 2a).

Another indication of a damaged membrane is the membrane porosity, as reflected by the amount of intracellular magnesium released. Challenge with $30 \mathrm{mM}$ octanoic acid resulted in the release of $46 \%$ more magnesium than the control sample (Fig. 2b).

These results confirm that exogenous SCFA challenge has a significant impact on both the fluidity and integrity of $E$. coli that was grown in the absence of SCFA. However, these results do not indicate which of these two effects is the most detrimental to growth or if either of these can be mitigated through the adaptive response. Given the fact that a short period of adaptation is sufficient to increase the resistance to growth inhibition by SCFAs, we repeated the quantification of
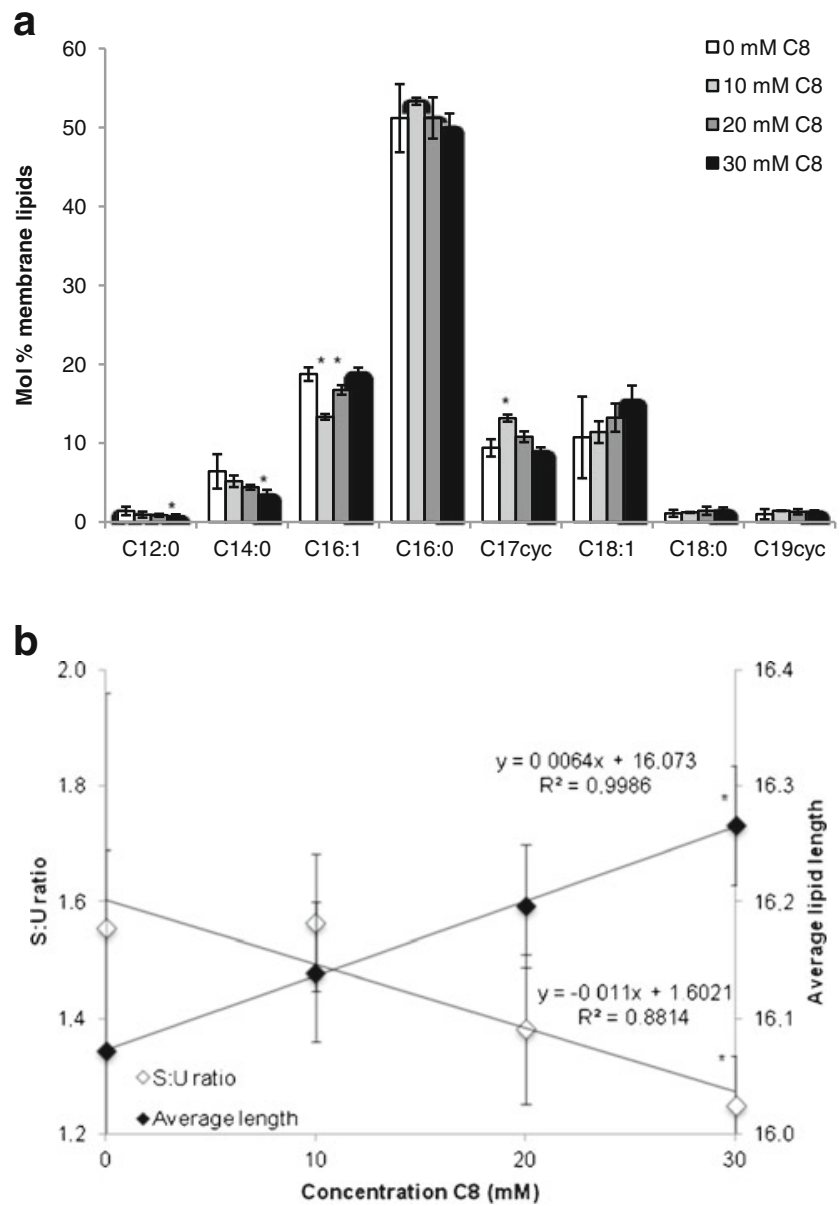

Fig. 3 During adaptation E. coli decreases the saturated/unsaturated ratio and increases the average lipid length. a Membrane lipid composition of log-phase $E$. coli cells adapted for $3 \mathrm{~h}$ to various concentrations of C8. C12:0 - lauric acid, C14:0 - myristic acid, C16:1 - palmitoleic acid, C16:0 - palmitic acid, C17cyc - cyclopropane C17:0, C18:1 vaccenic acid, C18:0 - stearic acid. b Mol ratio of saturated to unsaturated fatty acids and the weight-average lipid length after adaptation. An asterisk indicates a significant difference from the control $(0 \mathrm{mM})$ point $(p<0.05)$. The statistical significance of the linear regression estimates of the weight-average lipid length is available in Table S1

membrane fluidity and integrity using cells that had undergone $3 \mathrm{~h}$ of SCFA adaptation.

In contrast to the results seen for the unadapted cells, C8adapted $E$. coli were significantly more resistant to the fluidizing effects of octanoic acid under the concentrations tested (Fig. 2a). However, there was not a significant difference in the C8-mediated leakage between the adapted and unadapted cells (Fig. 2b).

These results suggest that during SCFA adaptation, the cell membrane is changed in a way that makes it resistant to the fluidizing effects of SCFAs, but not to the type of damage that induces a loss of integrity. An understanding of these changes could provide insight into both the mechanism of SCFA toxicity and means for increasing tolerance. 
Membrane lipids

In order to better understand the changes in the membrane that occur during adaptation and lead to maintenance of fluidity, we first quantified the membrane lipid composition for $E$. coli cells either grown in the control condition or adapted for $3 \mathrm{~h}$ to a variety of $\mathrm{C} 8$ concentrations (Fig. 3). As previously observed for bacteria, the membrane lipids can change upon environmental perturbations (Di Pasqua et al. 2007; Zhang and Rock 2008).

Interestingly, there was a sharp decrease in $\mathrm{C} 16: 1$ and an increase $\mathrm{C} 17$ cyc upon addition of $10 \mathrm{mM} \mathrm{C8}$; however, upon further addition of $\mathrm{C} 8$, the affect was reversed to the control value. The shorter lipids (C12:0 and C14:0) decreased whereas the longer lipids increased. The degree of change is apparent in the ratio of saturated to unsaturated lipids ( $\mathrm{S} / \mathrm{U}$ ratio) and the weight-averaged lipid length (Fig. 3b). The S/U ratio significantly decreased and the lipid length significantly increased upon $\mathrm{C} 8$ adaptation. This combined change of the $\mathrm{S} / \mathrm{U}$ ratio and the lipid length may be the mechanism behind the maintenance of the membrane fluidity.

\section{Surface hydrophobicity}

The bacterial cell membrane consists of lipids, proteins, peptidoglycans, and lipopolysaccharides (Raetz et al. 2007). In an effort to query the changes occurring during SCFA adaptation, we measured the effect of $\mathrm{C} 8$ on the surface hydrophobicity of outer membrane (Fig. S1). The $30 \mathrm{mM} \mathrm{C8-adapted} \mathrm{E.} \mathrm{coli} \mathrm{had} \mathrm{a}$ $\%$ MATH value of $5.0 \%$, which was much lower than unadapted E. coli at $22 \%$. The \%MATH value quantifies adhesion to hydrocarbons and thus indicates cell surface hydrophobicity. Unadapted $E$. coli adhered significantly to hydrocarbons, but the $30 \mathrm{mM} \mathrm{C8}$-adapted $E$. coli did not significantly adhere to hydrocarbons. Therefore, $\mathrm{C} 8$ adaptation can change the surface properties of the $E$. coli cell.

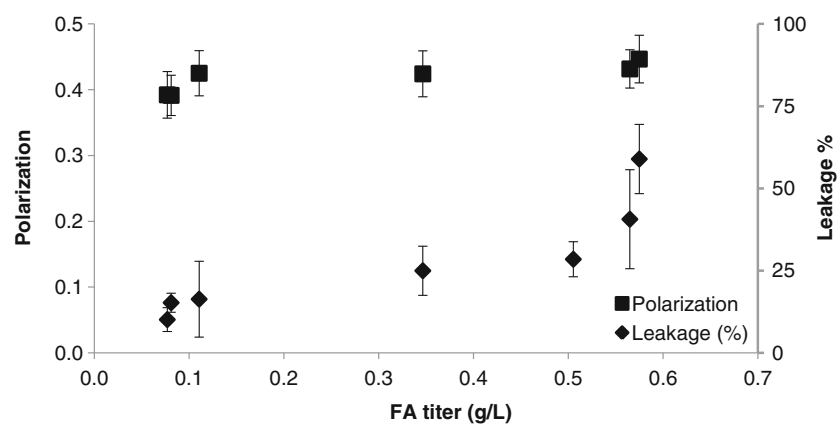

Fig. 4 Fatty acid production in strain ML103 + pXZ18Z is accompanied by increased membrane leakage but not a change in membrane fluidity. Membrane fluidity as measured by fluorescence polarization and membrane leakage as a function of the total fatty acid titer. The data represents the average of two simultaneously run fermenters. The error bars indicate the standard deviation
Effect of free fatty acid production on membrane integrity

The work described above analyzes the effect of free fatty acids on the wildtype E. coli. Through exogenous supplementation of SCFAs, we have observed that these compounds impact the membrane fluidity and leakage of unadapted cells; however, during adaptation changes in the membrane composition and hydrophobicity are accompanied by increased resistance to the fluidizing effect of these compounds, but not a change in the resistance to fatty acid-induced leakiness. However, our ultimate goal is to apply this knowledge to fatty acid producing strains, not just strains challenged with exogenous fatty acids. Therefore, we tested a recently described fatty acid production strain (San et al. 2011) for evidence of damaged cell membranes via changes in membrane fluidity and integrity (Fig. 4).

Specifically, we studied free fatty acid producing strain, ML103 + pXZ18Z (Ranganathan et al. 2012). This strain produced a final total fatty acid titer of $0.6 \mathrm{~g} / 1$ after $36 \mathrm{~h}$ fermentation in MOPS glucose minimal medium. The majority of the free fatty acids were produced during the stationary phase, and these were predominantly $\mathrm{C} 14: 0$ and C16:0.

Our measurement of membrane fluidity and leakage over the course of the fermentation demonstrated that fatty acid production was associated with a dramatic increase in the membrane leakage, but not a significant change in membrane fluidity (Fig. 4). Considering that fatty acid production can be considered analogous to adaptation, these results are consistent with our exogenous supplementation results. As the $E$. coli is producing free fatty acids in the stationary phase, it is also adapting to its environment by changing its membrane. Therefore, the same trends exist between the producer strain and the adaptation studies. Specifically, the fluidizing effects of fatty acids can be resisted by adaptation, but the fatty acidinduced leakage cannot. Additionally, the fatty acid-induced leakage is a problem with fatty acids longer than the model 8carbon compound that we focused on in this study.

\section{Discussion}

There is not much of a difference in the specific growth rate as the chain length of the fatty acid increases from six to eight carbons. The lower solubility of $\mathrm{C} 10$ in the medium may be an exception to the trends shown by C6 and C8 and was not studied further. In our system, C10 does not make micelles since it is above the melting temperature $\left(32^{\circ} \mathrm{C}\right)$, below the critical micelles concentration $(100 \mathrm{mM})$, and at neutral $\mathrm{pH}$ (Cistola et al. 1988). Therefore, it is assumed that the protonated $\mathrm{C} 10$ has a higher solubility within the membrane. The inhibition of $\mathrm{C} 8$ was further characterized by adjusting the medium $\mathrm{pH}$ (Fig. 1c). Upon addition of $\mathrm{C} 8$, the growth inhibition exhibited an exponential decay due to a shift in 
the concentration of the protonated form (Fig. 1d). Our results are in agreement with previous reports (Carpenter and Broadbent 2009; Kamp and Hamilton 2006; Ricke 2003; Russell 1991) that the protonated form is toxic to bacteria cells via permeation of the membrane to neutral lipophilic molecules and subsequent accumulation within the cell. Additionally, cell viability was measured by colony counting and PI assays, indicating that some cell death does occur upon addition of SCFAs.

It is known that $E$. coli cells are dynamic and are able to adapt in stressful environments in order to survive. Therefore, we used short-term adaptation to study how $E$. coli can change under SCFA stress. We have shown that adaptation can allow E. coli to be more tolerant of SCFAs (Fig. 1e) by maintenance of the optimal membrane fluidity and possibly by restructuring of the membrane composition and surface properties, such as hydrophobicity.

We have shown that addition of octanoic acid decreases fluorescence polarization, which indicates an increase in fluidity (Fig. 2a). Our measurements of membrane fluidity are in the range previously reported, between 0.28 and 0.37 (Mykytczuk et al. 2007). Membrane disruption is often a cause for toxicity of organic compounds, such as essential oils, cellulosic hydrolysates, and cyclic hydrocarbons (Di Pasqua et al. 2007; Mills et al. 2009; Sikkema et al. 1994). Membrane fluidity is one physiological element that can be used to quantify membrane damage and study membrane dynamics. Presumably, SCFAs, such as octanoic acid, impact the membrane fluidity and integrity due to their partial solubility within the membrane (Kamp and Hamilton 2006; Walter and Gutknecht 1984). Integration of octanoic acid into the cellular membrane may have an effect of increasing fluidity by reducing the hydrophobic interactions of the fatty acid tails as they flow laterally and transiently within the lipid bilayer.

It is known that bacteria are capable of changing their membrane composition in response to environmental conditions (Epand and Epand 2009). For example, the fatty acid profile of the membrane changes at different growth stages (De Siervo 1969). C8-adapted E. coli changed the membrane lipid composition (Fig. 3a), which possibly allows the cell to resist the fluidizing effects of SCFAs (Fig. 2a). The change in membrane lipid composition is characterized by a decrease in the $\mathrm{S} / \mathrm{U}$ ratio and a significant increase in the average lipid length (Fig. 3b). Although the change in the average lipid length is small, it is significant overall (Table S1). The lipid profile is dominated by C16:0, which accounts for $\sim 50 \%$ of the total lipids. It appears that $\mathrm{C} 8$-adapted E. coli increased $\mathrm{C} 17 \mathrm{cyc}$ at the expense of its precursor $\mathrm{C} 16: 1$ upon the addition of $10 \mathrm{mM} \mathrm{C} 8$. While there was no change in the $\mathrm{S} / \mathrm{U}$ ratio at $10 \mathrm{mM} \mathrm{C} 8$ adaptation, the lipid length increased. Cyclopropane lipids are often included in $\mathrm{S} / \mathrm{U}$ ratio calculations as it is believed to act similarly to unsaturated lipids (Zhang and Rock 2008). While there are many reports of E. coli changing the $\mathrm{S} / \mathrm{U}$ ratio in response to biofuels or solvents
(Huffer et al. 2011; Luo et al. 2009), there are few reports of a change in lipid length. Increasing the lipid length may increase the membrane lipid bilayer thickness (Lewis and Engelman 1983; Veld et al. 1991), which was not measured here. Alterations in the membrane thickness may also distort curvature and protein conformation, which may disrupt membrane protein functions (Engelman 2005; Veld et al. 1991). E. coli can use both the $\mathrm{S} / \mathrm{U}$ ratio and the average lipid length to retain the optimum membrane fluidity. Both an increase in the average lipid length and an increase in the $\mathrm{S} / \mathrm{U}$ ratio can increase the packing efficiency of the lipids within the membrane, thereby decreasing the membrane fluidity (Mykytczuk et al. 2007). Therefore, an increase in the average lipid length could counter-balance the decrease in the $\mathrm{S} / \mathrm{U}$ ratio to maintain the appropriate membrane fluidity. Bacteria cells have an elegant way of dynamically changing the lipid distribution in the membrane as a way of controlling the membrane properties.

Membrane leakage is a useful indicator of the porosity of the cellular membrane. While $E$. coli naturally uses passive transport for important nutrients, a leaky membrane is a costly burden. One of the most important functions of the cell membrane is to selectively exclude harmful compounds and retain valuable metabolites. We have shown here that octanoic acid significantly disrupts the cellular membrane, allowing intracellular metabolites to leak out. Interestingly, leakage caused by octanoic acid addition was unaffected by $\mathrm{C} 8$ adaptation (Fig. 2b), unlike adaptation in yeast as recently reported (Liu et al. 2013). Therefore, the E. coli cells do not have an adaptive mechanism to reduce membrane leakage.

If the membrane thickness has increased as an adaptive response to $\mathrm{C} 8$ stress, presumably there are more opportunities for increasing the membrane porosity by changing the natural lipid order. The extent of what passes through the membrane is unknown; another method may be useful for detection of larger biomolecules such as nucleotide leakage (Osman and Ingram 1985). Note that magnesium is critical for cellular function, including stabilization of the lipopolysacharide (LPS) layer in the outer membrane, folding of nucleic acids, binding of tRNA to amino acids, and participating in more than 300 enzymatic reactions (Walker 1994).

Finally, the surface hydrophobicity of unadapted and C8adapted E. coli was studied (Fig. S1). While unadapted $E$. coli had a \%MATH value of $22 \%$, C8-adapted E. coli had a value of only $5.0 \%$, indicating a decrease in cell surface hydrophobicity during adaptation. It is known that changes in the LPS layer of the outer membrane affect the cellular surface hydrophobicity (Aono and Kobayashi 1997; Li et al. 2012b). E. coli synthesizing more LPS develop an additional barrier to toxic hydrophobic chemicals. A change in the outer membrane permeability is known to aid cellular antibiotic resistance (Delcour 2009); therefore, it was not surprising that E. coli modified the cell surface properties in order to improve tolerance to SCFAs. 
Monocaprylate inhibition is about four times greater than octanoic acid inhibition (Hyldgaard et al. 2012). The difference is possibly due to the chemical structure, where the fatty acid is bonded to a glycerol molecule, allowing greater incorporation into the membrane bilayer. We suspect that monocaprylate may be acting much the same as free fatty acids. Our study of the membrane and how inhibitors such as C8 affect it are in agreement with previous studies (Huffer et al. 2011; Hyldgaard et al. 2012). Our study has taken further steps to quantify the degree of inhibition, the mode of action, and subsequent membrane alterations in a comprehensive report.

Hyldgaard et al. 2012 showed a morphological change when adding monocaprylate antibiotic to $E$. coli cells. Due to the similar nature of monocaprylate and octanoic acid, C8 may be changing the cellular morphology. Taken altogether, a change in the membrane lipid composition affects the membrane fluidity (Fig. 2a), porosity (Fig. 2b), transport (inferred from (Veld et al. 1991)), surface chemistry (Fig. S1), and cellular morphology (inferred from Hyldgaard et al. 2012; Mykytczuk et al. 2007).

Future studies to address SCFA toxicity could look at ways to alter the membrane composition of lipids as well as the surface hydrophobicity in an attempt to mitigate the perturbation of membrane properties. It may be that a design strategy for the production of SCFAs includes the production of long chain and unsaturated fatty acids for optimal membrane stability. It is possible to engineer the membrane; for example, it has been shown that an increase in saturated fatty acids in membrane composition can increase ethanol tolerance (Luo et al. 2009). Altering the membrane proteins may be also useful to reduce membrane permeability, neutralize fluidizing effects of membrane-soluble compounds, or restore protein functions.

SCFAs are desirable biorenewable chemicals; however, like many interesting biorenewable fuels and chemicals, these compounds are inhibitory to $E$. coli. A current challenge in strain engineering is a fast and reliable method for rationally engineering biocatalysts for the production of target molecules at industrially relevant yields, titers, and productivities. Our framework for studying inhibition and membrane damage may be helpful in the engineering design of biocatalysts for production of biorenewable chemicals, particularly those with partial solubility in the cell membrane. While this work is aimed at SCFAs, it can be applicable to a broad range of potential target biorenewable compounds.

Acknowledgments We thank Jennifer Au, an undergraduate in the CBiRC Research Experience for Undergraduates program from the University of Maryland, for her help with determination of growth rates. B.C. Hanson, a student at Skidmore University, participated in the CBiRC REU at Iowa State University and helped with the membrane lipid profiling. We thank Ann Perera and the W.M. Keck Metabolomics Research Laboratory at Iowa State University for the development of the membrane lipids extraction protocol. We thank Dr. Ka-Yiu San and Dr. Jong Moon Yoon for their help in GC-FID/MS lipids separation. We also thank Jacqueline Shanks, Ting Wei Tee, Kumar Kautharapu, Alexis Hoffman, and Fuyuan Jing for useful discussions. This work was supported by the NSF Engineering Research Center for Biorenewable Chemicals (CBiRC), NSF award number EEC-0813570. We thank the reviewers of this manuscript for their suggestions.

\section{Conflict of interest None.}

Open Access This article is distributed under the terms of the Creative Commons Attribution License which permits any use, distribution, and reproduction in any medium, provided the original author(s) and the source are credited.

\section{References}

Alonso DM, Bond JQ, Dumesic JA (2010) Catalytic conversion of biomass to biofuels. Green Chem 12(9):1493-1513

Aono R, Kobayashi H (1997) Cell surface properties of organic solventtolerant mutants of Escherichia coli K-12. Appl Environ Microbiol 63(9):3637-3642

Beney L, Mille Y, Gervais P (2004) Death of Escherichia coli during rapid and severe dehydration is related to lipid phase transition. Appl Microbiol Biotechnol 65(4):457-464. doi:10.1007/s00253-0041574-x

Bligh EG, Dyer WJ (1959) A rapid method of total lipid extraction and purification. Can J Biochem Physiol 37:911-917

Bozell JJ, Petersen GR (2010) Technology development for the production of biobased products from biorefinery carbohydrates - the US Department of Energy's "Top 10" revisited. Green Chem 12(4):539554. doi: $10.1039 / \mathrm{b} 922014 \mathrm{c}$

Brynildsen MP, Liao JC (2009) An integrated network approach identifies the isobutanol response network of Escherichia coli. Mol Syst Biol 5:277. doi:10.1038/msb.2009.34

Carpenter CE, Broadbent JR (2009) External concentration of organic acid anions and $\mathrm{pH}$ : key independent variables for studying how organic acids inhibit growth of bacteria in mildly acidic foods. J Food Sci 74(1):R12-R15. doi:10.1111/j.1750-3841.2008.00994.x

Centi G, van Santen RA (2007) Conclusions, perspectives and roadmap. In: Centi G, van Santen RA (eds) Catalysis for renewables: From feedstock to energy production. Wiley-VCH Verlag, Weinheim, Germany, pp 387-411. doi:10.1002/9783527621118.oth1

Chambers M, Muecke M (2010) Biobased products and the LEED ${ }^{\circledR}$ rating system. J Green Build 5(4):91-107. doi:10.3992/jgb.5.4.91

Chen GQ, Xu J, Wu Q, Zhang Z, Ho KP (2001) Synthesis of copolyesters consisting of medium-chain-length $\beta$-hydroxyalkanoates by Pseudomonas stutzeri 1317. React Funct Polym 48(1):107-112. doi:10. 1016/s1381-5148(01)00042-6

Cistola DP, Hamilton JA, Jackson D, Small DM (1988) Ionization and phase behavior of fatty acids in water: application of the Gibbs phase rule. Biochemistry 27(6):1881-1888. doi:10.1021/bi00406a013

Cummings JH, Macfarlane GT (1991) The control and consequences of bacterial fermentation in the human colon. J Appl Microbiol 70(6):443-459. doi:10.1111/j.1365-2672.1991.tb02739.x

De Siervo AJ (1969) Alterations in the phospholipid composition of Escherichia coli B during growth at different temperatures. J Bacteriol 100(3):1342-1349

Delcour AH (2009) Outer membrane permeability and antibiotic resistance. Biochim Biophys Acta: Protein Proteomics 1794(5):808 816. doi:10.1016/j.bbapap.2008.11.005 
Desbois A, Smith V (2010) Antibacterial free fatty acids: activities, mechanisms of action and biotechnological potential. Appl Microbiol Biotechnol 85(6):1629-1642. doi:10.1007/s00253-009-2355-3

Di Pasqua R, Betts G, Hoskins N, Edwards M, Ercolini D, Mauriello G (2007) Membrane toxicity of antimicrobial compounds from essential oils. J Agric Food Chem 55(12):4863-4870. doi:10.1021/jf0636465

Diez-Gonzalez F, Russell JB (1999) Factors affecting the extreme acid resistance of Escherichia coli O157:H7. Food Microbiol 16(4):367374. doi:10.1006/fmic.1998.0249

DOE US (2012) Energy Department announces awards to projects advancing innovative clean coal technology. U.S. Department of Energy. http://energy.gov/articles/energy-department-announces-awardsprojects-advancing-innovative-clean-coal-technology

Engelman DM (2005) Membranes are more mosaic than fluid. Nature 438(7068):578-580

Epand RM, Epand RF (2009) Lipid domains in bacterial membranes and the action of antimicrobial agents. Biochim Biophys Acta Biomembr 1788(1):289-294. doi:10.1016/j.bbamem.2008.08.023

Erickson B, Nelson JE, Winters P (2012) Perspective on opportunities in industrial biotechnology in renewable chemicals. Biotechnol J 7(2):176-185. doi:10.1002/biot.201100069

Huffer S, Clark ME, Ning JC, Blanch HW, Clark DS (2011) Role of alcohols in growth, lipid composition, and membrane fluidity of yeasts, bacteria, and archaea. Appl Environ Microbiol 77(18):6400 6408. doi:10.1128/aem.00694-11

Hyldgaard M, Sutherland DS, Sundh M, Mygind T, Meyer RL (2012) Antimicrobial mechanism of monocaprylate. Appl Environ Microbiol 78(8):2957-2965. doi:10.1128/aem.07224-11

Jarboe L, Grabar T, Yomano L, Shanmugan K, Ingram L (2007) Development of ethanologenic bacteria. In: Olsson L (ed) Advances in biochemical engineering/biotechnology, vol 108, Springer. Berlin, Germany, pp 237-261

Jarboe LR, Liu P, Royce LA (2011) Engineering inhibitor tolerance for the production of biorenewable fuels and chemicals. Curr Opin Chem Eng 1(1):38-42. doi:10.1016/j.coche.2011.08.003

Kabara J (1984) Antimicrobial agents derived from fatty acids. J Am Oil Chem Soc 61(2):397-403. doi:10.1007/bf02678802

Kabara JJ, Marshall DL (2005) Medium-chain fatty acids and esters. In: Davidson PM, Sofos JN, Branen AL (eds) Antimicrobials in food, 3rd edn. Taylor and Francis Group, Boca Raton, pp 327360

Kamp F, Hamilton JA (2006) How fatty acids of different chain length enter and leave cells by free diffusion. Prostaglandins Leukot Essent Fat Acids 75(3):149-159. doi:10.1016/j.plefa.2006.05.003

Kirkpatrick C, Maurer LM, Oyelakin NE, Yoncheva YN, Maurer R, Slonczewski JL (2001) Acetate and formate stress: opposite responses in the proteome of Escherichia coli. J Bacteriol 183(21):6466-6477. doi:10.1128/jb.183.21.6466-6477.2001

Lennen RM, Pfleger BF (2013) Modulating membrane composition alters free fatty acid tolerance in Escherichia coli. PLoS One 8(1):e54031. doi:10.1371/journal.pone.0054031

Lennen RM, Kruziki MA, Kumar K, Zinkel RA, Burnum KE, Lipton MS, Hoover SW, Ranatunga DR, Wittkopp TM, Marner WD II, Pfleger BF (2011) Membrane stresses induced by overproduction of free fatty acids in Escherichia coli. Appl Environ Microbiol 77(22):8114-8128. doi:10.1128/aem.05421-11

Lewis BA, Engelman DM (1983) Lipid bilayer thickness varies linearly with acyl chain length in fluid phosphatidylcholine vesicles. J Mol Biol 166(2):211-217. doi:10.1016/s0022-2836(83)80007-2

Li M, Zhang X, Agrawal A, San K-Y (2012a) Effect of acetate formation pathway and long chain fatty acid CoA-ligase on the free fatty acid production in E. coli expressing acyl-ACP thioesterase from Ricinus communis. Metab Eng 14(4):380-387. doi:10.1016/j.ymben.2012. 03.007

Li Y, Powell DA, Shaffer SA, Rasko DA, Pelletier MR, Leszyk JD, Scott AJ, Masoudi A, Goodlett DR, Wang X, Raetz CRH, Ernst RK (2012b) LPS remodeling is an evolved survival strategy for bacteria. PNAS 109(22):8716-8721. doi:10.1073/pnas.1202908109

Liu P, Chernyshov A, Najdi T, Fu Y, Dickerson J, Sandmeyer S, Jarboe L (2013) Membrane stress caused by octanoic acid in Saccharomyces cerevisiae. Appl Microbiol Biotechnol 97(7):3239-3251. doi:10. 1007/s00253-013-4773-5

Luo L, Seo P-S, Seo J-W, Heo S-Y, Kim D-H, Kim C (2009) Improved ethanol tolerance in Escherichia coli by changing the cellular fatty acids composition through genetic manipulation. Biotechnol Lett 31(12):1867-1871. doi:10.1007/s10529-009-0092-4

Mäki-Arvela P, Kubickova I, Snare M, Eränen K, Murzin DY (2007) Catalytic deoxygenation of fatty acids and their derivatives. Energy Fuel 21(1):30-41. doi:10.1021/ef060455v

Makkar R, Cameotra S (2002) An update on the use of unconventional substrates for biosurfactant production and their new applications. Appl Microbiol Biotechnol 58(4):428-434. doi:10.1007/s00253001-0924-1

Mills TY, Sandoval NR, Gill RT (2009) Cellulosic hydrolysate toxicity and tolerance mechanisms in Escherichia coli. Biotechnol Biofuels 2(26):26. doi:10.1186/1754-6834-2-26

Minty JJ, Lesnefsky AA, Lin FM, Chen Y, Zaroff TA, Veloso AB, Xie B, McConnell CA, Ward RJ, Schwartz DR, Rouillard JM, Gao YA, Gulari E, Lin XN (2011) Evolution combined with genomic study elucidates genetic bases of isobutanol tolerance in Escherichia coli. Microb Cell Fact 10:18. doi:10.1186/1475-2859-10-18

Mykytczuk NCS, Trevors JT, Leduc LG, Ferroni GD (2007) Fluorescence polarization in studies of bacterial cytoplasmic membrane fluidity under environmental stress. Prog Biophys Mol Biol 95(13):60-82. doi:10.1016/j.pbiomolbio.2007.05.001

Nikolau BJ, Perera MADN, Brachova L, Shanks B (2008) Platform biochemicals for a biorenewable chemical industry. Plant J 54(4):536-545. doi:10.1111/j.1365-313X.2008.03484.x

Osman YA, Ingram LO (1985) Mechanism of ethanol inhibition of fermentation in Zymomonas mobilis CP4. J Bacteriol 164(1):173180

Polen T, Rittmann D, Wendisch VF, Sahm H (2003) DNA microarray analyses of the long-term adaptive response of Escherichia coli to acetate and propionate. Appl Environ Microbiol 69(3):1759-1774. doi:10.1128/aem.69.3.1759-1774.2003

Raetz CRH, Reynolds CM, Trent MS, Bishop RE (2007) Lipid A modification systems in gram-negative bacteria. Annu Rev Biochem 76(1):295-329. doi:10.1146/annurev.biochem.76.010307.145803

Ranganathan S, Tee TW, Chowdhury A, Zomorrodi AR, Yoon JM, Fu Y, Shanks JV, Maranas CD (2012) An integrated computational and experimental study for overproducing fatty acids in Escherichia coli. Metab Eng 14(6):687-704. doi:10.1016/j.ymben.2012.08.008

Reyes LH, Almario MP, Kao KC (2011) Genomic library screens for genes involved in $n$-butanol tolerance in Escherichia coli. PLoS One 6(3):e17678. doi:10.1371/journal.pone.0017678

Ricke S (2003) Perspectives on the use of organic acids and short chain fatty acids as antimicrobials. Poult Sci 82(4):632-639

Russell AD (1991) Mechanisms of bacterial resistance to non-antibiotics: food additives and food and pharmaceutical preservatives. J Appl Microbiol 71(3):191-201. doi:10.1111/j.1365-2672.1991.tb04447.x

San K, Li M, Zhang X (2011) Bacteria and method for synthesizing fatty acids. U.S. Patent, WO/2011/116279

Shanks BH (2010) Conversion of biorenewable feedstocks: new challenges in heterogeneous catalysis. Ind Eng Chem Res 49(21):10212-10217. doi:10.1021/ie100487r

Sikkema J, de Bont JA, Poolman B (1994) Interactions of cyclic hydrocarbons with biological membranes. J Biol Chem 269(11):80228028

Tvrzická E, Vecka M, Stanková B, Zak A (2002) Analysis of fatty acids in plasma lipoproteins by gas chromatography-flame ionization detection: quantitative aspects. Anal Chim Acta 465:337-350. doi:10.1016/S0003-2670(02)00396-3 
Veld GI, Driessen AJM, Op den Kamp JAF, Konings WN (1991) Hydrophobic membrane thickness and lipid-protein interactions of the leucine transport system of Lactococcus lactis. Biochim Biophys Acta Biomembr 1065(2):203-212. doi:10.1016/0005-2736(91)90231-v

Wackett LP (2008) Microbial-based motor fuels: science and technology. Microb Biotechnol 1(3):211-225. doi:10.1111/j.1751-7915.2007. 00020.x

Walker GM (1994) The roles of magnesium in biotechnology. Crit Rev Biotechnol 14(4):311-354. doi:10.3109/07388559409063643

Walter A, Gutknecht J (1984) Monocarboxylic acid permeation through lipid bilayer membranes. J Membr Biol 77(3):255-264. doi:10. 1007/bf01870573

Wanner BL (1994) Gene expression in bacteria using tnphoA and tnphoA' elements to make and switch phoA gene, lacZ (op), and lacZ(pr) fusions. In: Adolph KW (ed) Methods in molecular genetics, vol 3, Academic Press. Orlando, Fl, pp 291-310

Yang J, Hou X, Mir PS, McAllister TA (2010) Anti-Escherichia coli $\mathrm{O} 157: \mathrm{H} 7$ activity of free fatty acids under varying $\mathrm{pH}$. Can J Microbiol 56(3):263-267. doi:10.1139/w09-127

Zhang Y-M, Rock CO (2008) Membrane lipid homeostasis in bacteria. Nat Rev Micro 6(3):222-233

Zhang X-S, García-Contreras R, Wood TK (2007) ycfR (bhsA) influences Escherichia coli biofilm formation through stress response and surface hydrophobicity. J Bacteriol 189(8):3051-3062. doi:10.1128/ jb.01832-06

Zhang FZ, Rodriguez S, Keasling JD (2011) Metabolic engineering of microbial pathways for advanced biofuels production. Curr Opin Biotechnol 22(6):775-783. doi:10.1016/j.copbio.2011.04.024 